\title{
Oral health assessment in school program health: who and how?
}

\author{
Avaliação de saúde bucal no programa saúde na escola: quem e como?
}

\author{
Erick Ely Gomes de OLIVEIRA ${ }^{1}$ \\ (iD) ORCID iD 0000-0002-0026-1361 \\ Diandra Costa ARANTES 1 \\ (iD) ORCID iD 0000-0001-9220-987X \\ Liliane Silva do NASCIMENTO' \\ (iD) ORCID iD 0000-0002-5943-6314 \\ Flávia Sirotheau Correa PONTES 1 \\ (iD) ORCID iD 0000-0003-3042-2880
}

\section{ABSTRACT}

Oral health is a constitutional right, with its own national policy which guides the relevance of its interrelation to general health within the integrality principles. This manuscript aims at understanding how oral health assessment and actions are observed within the School Program Health, through a qualitative study performed in the city of Belém, State of Pará, Brazil. The sample criterion consisted of 5 nurses, 5 teachers and 5 parents. A semi-structured script was used, written and transcribed with subsequent thematic analysis. The analysis revealed three thematic categories emphasizing the need for policy empowerment and practice in order to understand the meanings of oral health within the SHP as well as to enlarge its specificity in the interdisciplinary work scenario. Thus, it is clear that for the effective functioning of the school I health relationship, it is of utmost importance that SHP policy is applied and recognized while continuously seeking to strengthen the principle of integrality and extended clinic. The study also highlights permanent education and constant need for the participants' skill improvement so that both students' health care and life quality can be fully promoted.

Indexing terms: Primary health care. Education, dental. School health services.

\section{RESUMO}

A saúde bucal apresenta-se como um direito constitucional, sendo condição relevante à integralidade de saúde. Este artigo objetivou compreender como a avaliação e ações de saúde bucal são contempladas no âmbito do Programa Saúde na Escola, através de pesquisa com abordagem qualitativa no município de Belém, Pará, utilizando roteiro semiestruturado com amostra de três categorias do Programa Saúde na Escola, selecionadas por conveniência e com base no critério de saturação: enfermeiros, professores e pais. A análise resultou três categorias distintas e inter-relacionadas que ressaltam a discussão acerca da necessidade de empoderamento para compreensão dos significados da saúde bucal dentro do PSE e ampliação de sua especificidade no cenário de trabalho transdisciplinar. Para o efetivo funcionamento da articulação escola/saúde, faz-se necessário reconhecer a aplicabilidade da política do Programa Saúde na Escola, buscando cada vez mais implementála nas escolas de modo a otimizar a interligação entre os envolvidos. Verificou-se a constante necessidade acerca do aperfeiçoamento de habilidades dos atores deste cenário de modo a atuar munidos de atitudes/comportamentos adequados para a melhoria da qualidade de vida do escolar.

Termos de indexação: Atenção básica à saúde. Educação em Odontologia. Serviços de saúde escolar.

\section{INTRODUCTION}

The concept of health, a fundamental human right, has been changing, over the years, worldwide. In Brazil, it is as a constitutional right, which guides all citizens about the basic principles of citizenship and it represents an important users' tool towards their rights and duties in the health system [1]. In this sense, health care implies actions of individual, collective participation and political management concerning goal planning and performance as well as the work development in the expanded concept of health [2-6].

The professional assistance of child health, defined as Childcare, can be understood as a "science which brings notions of Psychology, Hygiene, Sociology all together in order to favor children's physical and psychical development from the gestation period until puberty" [7]. Thus, for the child's and adolescent's integral health maintenance, it is essential that their growth and development be followed once they represent important ground for multiprofessional activities in the biological, affective, psychic and social aspects $[8,9]$.

Oral health, an important condition for health comprehensiveness, plays an essential role in health maintenance, since oral disorders such as: malnutrition, infections, late dental eruptions and other diseases $[10,11]$

\footnotetext{
${ }^{1}$ Universidade Federal do Pará, Faculdade de Odontologia. Rua Augusto Correa, 1, Guamá, 66075-110, Belém, PA, Brasil. Correspondência para / Correspondence to: LS NASCIMENTO. E-mail: < lilianenascimento2001@gmail.com >.

$\boldsymbol{v} \mathbf{v} \boldsymbol{v}$

Como citar este artigo / How to cite this article

Oliveira EEG, Arantes DC, Nascimento LS, Pontes FSC. Oral health assessment in school program health: who and how?. RGO, Rev Gaúch Odontol. 2018;66(2):00-00. http://dx.doi.org/10.1590/1981-863720180002000083416
} 
represent direct negative effects on the children's and adolescents' health and life quality. In Brazil, oral health prevention and education programs are almost exclusively focused on the prevention of dental caries, therefore a better analysis of each group/region dental needs must be perfomed $[12,13]$. The relationship between school and health actions have not been recent and reports show that in the late nineteenth century and especially in the first half of the XX century, health actions became part of the Brazilian school environment in order to regulate and guide some actions within the school [14].

The School Health Program (SHP), established in 2007, has provided services within a territory where both planning, performance, monitoring and evaluation of actions are collectively carried out, in order to meet the local demand needs [15]. In the activities proposed by the SHP, Dentistry is responsible for identifying signs and symptoms related to biological changes in students enrolled in the schools which participate in the program through assessments and monitoring of child's and adolescent's development [16]. This study aims at understanding how the assessment and actions of oral health are perceived within the scope of the Health in School Program.

\section{METHODS}

The study consisted of a qualitative research, whose data collection was carried out from December 2014 to February 2015 in the city of Belém / State of Pará, through a recorded interview applied by a single researcher, following a semi-structured questionnaire.

A random draw was performed and the participants were selected according to the municipal schools under the SHP. The numerical delimitation of each category followed the saturation criterion [17], considering SHP participants of both sexes and of three categories as follows: nurses, teachers and parents. The choice was made based on the policy criterion which is directly linked to the Ministry of Education. The SHP has interministerial financial resources which are interconnected with the family health unit actions, however this is not a policy criterion. Each municipality has its own SHP membership as well as supervision and monitoring staff not necessarily linked to health teams. Strategic points, within the school settings, are then defined. Thus, five nurses from the municipal primary health care, five teachers from the municipal education network and five parents / guardians from school enrolled in the municipal school network of Belém participated in the study. Inclusion criterion consisted of at least six-month previous experience in the municipal health and education network as well as with the SHP. Professionals who were not included in the context of the SHP, as well as those with less 6-month experience were excluded.

The municipality has 1,450,699 inhabitants, divided into eight districts, from which $23 \%$ are in basic care and $4.5 \%$ in oral health [18]. The sample was selected from two districts: Mosqueiro Administrative District (DAMOS) and Icoaraci Administrative District (DAICO), which were selected once they represent the Amazonian reality and the territorialization of the health and education network, as well.

The DAMOS district, comprising the island of Mosqueiro, has 27,896 inhabitants in its territory, $2.2 \%$ of the total population of the districts of Belém. Concerning education, DAMOS has 1026 early education school students enrolled in the municipal education network, 4790 in primary education and 1024 in youth and adult education (EJA), in a total of 6840 students [19].

The DAICO district has 133,150 inhabitants in its territory, $10.4 \%$ of the inhabitants of Belém [18]. As education is concerned, DAICO has 1643 students enrolled in early childhood education, 7334 in high school and 2041 in EJA [20].

The participants signed a Free and Informed Consent Term, the interviews were digitalized and printed in full by the researcher, so that the statements were coded and categorized in order to identify the thematic core. The results were analyzed by two experienced researchers according to the method of Content Analysis, proposed by Bardin [21].

This research was approved by the Research Ethics Committee of the Health Sciences Institute of the Federal University of Pará (under number $1,016,706$ ), the Declaration of Helsinki was respected, and the guidelines and principles of Resolution of the National Health Council $n^{\circ} 466 / 2012$ and 251/1997 were followed.

\section{RESULTS}

The interviews (15) were analyzed under the content analysis, which showed three distinct and interrelated categories: 1:"Oral Health ... one should have it, but he/she does not "; 2) "Oral Health in the SHP and 3) "In the referral ... caries is the main aggravating factor". For the sake of participants' identity protection, each one was assigned according to the participating category, followed 
by numbers from 01 to 05 , related to the chronological order of interviews.

\section{DISCUSSION}

Understanding the meanings of oral health within the SHP enlargens its specificity and places interdisciplinary work on the scene. The policy extent focusing on the promotion and prevention of school health should potentially promote health and quality of life through health actions among those the identification and performance of tasks related to oral health conditions, which enhance the individual as a whole.

Brazil is at the top of the "ranking" of oral diseases where $100 \%$ of the population presents caries and / or periodontal diseases. The percentage of two-year-olds with caries is 56\%; when 12 years old group is analyzed, the average number of decayed teeth is seven teeth; the result is even more regrettable when it comes to the 60-year-old group who presents only six to eight natural teeth in their entire dental arch [22].

For this category, the following statements pointed precarious oral health, in view of conflicting issues which impaired positive progress in the development of activities.

"[...] Well ... I think oral health at school, is very precarious" (Responsible 05).

"[...] we also need a dental support, something that the

There is no strategy..., do you understand? ?" (Nurse 02

The school stands out as a privileged scenario for such change implementions once it is a place of teaching propagation (including health) which also promotes good relationship with the students and their parentes. Therefore planning interdisciplinary and multiprofessional actions for school oral health care, with the presence of the dentist is of utmost importance in order to provide new knowledge regarding health-disease-care, favoring an integration with the other collective health practices by the multidisciplinary team of the family health teams. Primary health care and consequently the well-being of the population [23-25] can receive greater resolvability [23-25]. The participants have shown significant understanding of oral health as a prevention strategy, however, this has not been performed as recommended by the National Oral Health Policy due to lack of material and qualified professional. The implementation of oral health promotion practices have been put aside while other pedagogical school projects are favored.

2- Oral Health at the SHP

The National Oral Health and the SHP policies ensure professionals' and users' dignity, aiming at the quality of the services provided, through tripartite and intersecretarian agreements between education and health, in order to guide integrated work based on the health needs of the school population. However, in the teachers' statements, presented below, the dissociation of these partnerships in the reality to which they are inserted is clear.

"[...] I understand that a better school partnership with other entities is necessary in order to improve ..." (Teacher 04).

"[...] The government itself should pay attention to this." (Teacher 02).

For better professional, pedagogical and health practices aiming at the organization of services, the Ministry of Health / Education advocate the agreement between Schools and Health Units, promoting permanent and continuing health education towards teachers, parents and students, where educational interventions should not only target individuals but issues which interfere in the organization and environment as well as health behavior and interpersonal relationship.

The participating population in educational approaches can intervene in the learning process and should influence and possess its own atributes where teaching methodologies must be adapted to each reality. For this to effectively occur effectively, it is necessary to fulfill some criteria such as performance, in a dynamic and perennial way and not just occasionally [26-28]. The analysis emphasizes the importance of networking between the school and the basic health network which is essential in the consolidation of health promotion actions and in the enhancement of health care in childhood and youth.

School is a place of learning and being. Schools are factories organized for the production of mobile biopsychological units carrying knowledge and skills. Thus, health-related themes in the daily school life, based on this understanding may potentially reach a large number of individuals and, given its educational character, be effective in changing behaviors and habits [29]. On the other hand, the following testimony shows that these activities are prone to discontinuity due to the fragile relationship with the contents developed in the classroom and the theoretical-practical school process, as a whole. 
"In the old days, when I was a student ... there was a campaign that taught me the right way to brush my teeth and such things ... but today I do not see them" (Teacher 02).

The inclusion of health-related themes in the school provides students with the understanding of health condition, especially disorders (whether dental or not), can not be considered as spontaneous but rather as a set of pre-disposed factors which can trigger unpleasant health events.

Despite how complex being a teacher can be, the school is seen as a privileged space for health action and training, where school health strategies should stimulate the flexibility of school curricula, thus creating institutions where planning will be integrated into education / health, providing na integral and participatory approach, leading the individual to develop skills and the awareness of being responsible for his own life.

"In referrals ... caries is the main aggravating factor"

In order to improve positive sucessful changes in the SHP, it is essential to instrumentalize risk classification and the need for treatment boosting methodologies which include, in fact, the dentist and other professionals from diferent areas.

The work of nurses in the SHP require interaction with school and health professionals, once the need for dental treatment is not always performed by a dental professional, a limiting and debatable issue in the school health policy [26]. Sometimes, due to the dentist's absence in the SHP, the nurse performs oral health assessment, in order to orientation towards oral hygiene, teeth care and prevention of caries [16].

Thus, referral as a tool aims to ensure students' oral health care actions, referring them to the dental unit usually near the school without developing bonds or other etiological factors of caries disease or yet other student's oral health risks that could be identified [16].

For teachers, evaluation / referral and even pathology perception seem to be a distant and inappropriate scenario. The facto $f$ feeling co-responsible for the oral health of their schoolchildren are perceived in the speeches:

"[...] Make an evaluation of the minimum that I know is ... of ... academic formation." (Nurse 03).

"... I sincerely do not have it, it never crossed my mind, as a teacher, to come and say like 'Look at that boy's needs!' Never." (Professor 05).
In Brazil, didactic-informative materials have been constantly published in order to guide the school professionals in relation to other themes. Specifically in the health-oriented materials, it is stated that educational practices should be carried out in order to promote students' awareness about their health rights, favoring the understanding of health promotion, protection and recovery [30].

In the words "[...] What I understand as referral within this, are children with process of ... is ... extraction, needing extraction, caries ... so caries is the main aggravating factor." (Nurse 02); and "[...] Ah, specifically it is important when the students express their needs since I can not impose to them the type of treatment. It is necessary that he/she expresses them and from there forward". Teacher 1). These interrelated testimonies are observed and understood as normal and pathological, which becomes the main indicative for referrals.

One must at least acknowledge a fact in order to act. In this way, a person is healthy insofar as he follows environment fluctuations, especially the physiological. Thus, healing is the recovery of a state of physiological standard stability. It will be closer either to disease or health once such stability is more or less prone to modifications [31].

For the SHP, the nurse and the teacher practices are essential in the development and improvement of skills in order to identify the students who need follow-up, and it is a must that these professionals establish routine activities which later can enhance students' reception.

\section{FINAL CONSIDERATIONS}

It is observed in the SHP policy that the teachers and nurses have been assuming roles of health promoters and randomly identified injuries without training and back support by the health team. This fact implies in under reporting and real oral health problem invisibility. It is recommended that the SHP consider the health professionals, in the case of this study - the dentist, in order to have an effective impact of health promotion and disease reduction due to oral pathologies. It is also important to emphasize the team permanent education and skill improvement in order to strengthen appropriate attitudes I behaviors to enchance the quality of life. Finally, for the effective functioning of the school / health relationship, it is necessary to recognize both appliable and transversal SHP policy actions interrelated with the National Oral Health Policy. 


\section{REFERENCES}

1. Presidência da República. Casa Civil. Subchefia para Assuntos Jurídicos. Constituição (1988). Constituição da República Federativa do Brasil. Brasília, DF: Casa Civil; 1988 [citado 2017 Out 12]. Disponível em: <http://www.planalto.gov.br/ccivil_03/ constituicao/constituicao.htm>.

2. Brasil. Ministério da Saúde. Carta dos direitos dos usuários da saúde. $3^{a}$ ed. Brasília: Ministério da Saúde; 2011 [citado 2017 Out 12]. Disponível em: <http://www.use.ufscar.br/direitos-edeveres-dos-usuarios/carta-direitos-usuarios>.

3. Minayo MCS, Hartz ZMA, Buss PM. Qualidade de vida e saúde: um debate necessário. Ciênc Saúde Coletiva. 2000;5(1):7-18. doi: 10.1590/S1413-81232000000100002

4. Brousse C, Boisaubert B. Quality of life and escales measuring Med Pregl. 1998 Jan-Feb;51(1-2):37-40.

5. Seidl EMF, Zannon CMLC. Qualidade de vida e saúde: aspectos conceituais e metodológicos. Cad Saúde Pública. 2004;20(2):580-8. doi: 10.1590/S0102-311X2004000200027

6. Campos MO, Neto JFR. Qualidade de vida um instrumento para promoção de saúde. Rev Baiana Saúde Pública. 2008;32(2):232240.

7. Blank D. A puericultura hoje: um enfoque apoiado em evidências. J Pediatr. 2003;79:13-22. doi: 10.1590/S002175572003000700003

8. Sapienza G, Pedromônico MRM. Risco, proteção e resiliência no desenvolvimento da criança e do adolescente. Psicol Estud. 2005;10(2):209-16. doi: 10.1590/S141373722005000200007

9. Brasil. Ministério da Saúde. Secretaria de Políticas de Saúde. Departamento de Atenção Básica. Saúde da criança: acompanhamento do crescimento e desenvolvimento infantil. Brasília: Ministério da Saúde; 2002 [citado 2017 Out 12]. Disponível em: <http://bvsms.saude.gov.br/bvs/publicacoes/ crescimento_desenvolvimento.pdf>.

10. Geniole LAl. Saúde bucal por ciclos de vida. Campo Grande: Ed UFMS/Fiocruz Unidade Cerrado Pantanal; 2011

11. Tomita NE, Vitoriano TB, Eymar SL, Franco LJ. Prevalência de cárie dentária em crianças da faixa etárias de 0 a 6 anos matriculadas em creches: importância de fatores socioeconômicos. Rev Saúde Pública. 1996;30(5):413-20. doi: 10.1590/S003489101996000500003

12. Barbosa TS, Mialhe FL, Castilho ARF, Gavião MBD. Qualidade de vida e saúde bucal em crianças e adolescentes: aspectos conceituais e metodológicos. Physis. 2010;20(1):283-300. doi: 10.1590/S0103-73312010000100015

13. Nickel DA, Lima FG, Silva BB. Modelos assistenciais em saúde bucal no Brasil. Porto Alegre: Artmed; 2003

14. Collares CAL, Moysés MAA. Educação ou Saúde? Educação X Saúde? Educação e Saúde! Cadernos Cedes. 1985;15:7-16.

15. Brasil. Presidência da República. Decreto $n^{\circ}$ 6.286. Institui o Programa Saúde na Escola - PSE, e dá outras providências.
Programa Saúde na Escola. Brasília: Presidência da República 2007 [citado 2017 Out 12]. Disponível em: <http://www. planalto.gov.br/ccivil_03/_ato2007-2010/2007/decreto/d6286. htm>.

16. Brasil. Ministério da Saúde. Secretaria de Atenção à Saúde Departamento de Atenção Básica. Cadernos de Atenção Básica $n^{\circ}$ 24: Saúde na escola. Brasília: Ministério da Saúde; 2009 [citado 2017 Out 12]. Disponível em: <http://189.28.128.100/ dab/docs/publicacoes/cadernos_ab/abcad24.pdf>.

17. Minayo MCS. O desafio do conhecimento: pesquisa qualitativa em saúde. 9a ed. São Paulo: Hucitec; 2006.

18. Brasil. Ministério da Saúde. Histórico de Cobertura da Saúde da Família [citado 2017 Maio 12]. Disponível em: <http://dab. saude.gov.br/dab/historico_cobertura_sf/historico_cobertura_ sf_relatorio.php>.

19. Prefeitura Municipal de Belém. Dados Populacionais [citado 2017 Maio 12]. Disponível em: <Disponível em: www.belem. pa.gov.br>

20. Instituto Nacional de Estudos e Pesquisas Educacionais Anísio Teixeira. Consulta à matrícula [citado 2017 Maio 8]. Disponível em: <www.portal.inep.gov.br/basica-censo-escolarmatricula>

21. Bardin L. Análise de conteúdo. Lisboa: Edições 70; 1977.

22. Nickel DA, Lima FG, Silva BB. Modelos assistenciais em saúde bucal no Brasil. Porto Alegre: Artmed; 2003.

23. Alves R. Correio Popular, Caderno C. Escola da Ponte (publicada originalmente com o título "Quero uma escola retrógrada") [citado 2017 Maio 12]. Disponível em: <http://www.rubemalves. com.br/escoladaponte1.htm>.

24. Paresque $M A C$, Aragão DS, Fernandes $M B L$, Santos MLMF, Mendes JDR, Pereira PM. A atenção em saúde bucal e a operacionalização das suas práticas na Estratégia em Saúde da Família a partir da Residência Multiprofissional no município de Sobral- CE. Sanare (Sobral). 2009;8(2):73-82.

25. Lemkuhl I, Souza MVC, Cascaes AM, Bastos JL. A efetividade das intervenções educativas em saúde bucal: revisão de literatura. Cad Saúde Coletiva. 2015;23(3):336-46. doi: 10.1590/1414$462 \times 201400030104$

26. Mendes JDR, Freitas CAS, Dias MSA, Fernandes DR. Análise das atividades de educação em saúde realizadas pelas equipes de saúde bucal. Rev Bras Promoção da Saúde. 2017;30(1):13-21.

27. Paresque MAC, Taboza Z, Dias C, Francelino R. Ressignificando as práticas na atenção em saúde bucal aos escolares. Sanare (Sobral). 2011;10(1):49-53.

28. Monteiro PHN, Bizzo N. A saúde na escola: análise dos documentos de referência nos quarenta anos de obrigatoriedade dos programas de saúde, 1971-2011. História, Ciências, Saúde (Manguinhos). 2013;22(2):411-27.

29. Brasil. Ministério da Saúde. Secretaria de Atenção à Saúde. Departamento de Atenção Básica. Política Nacional de Atenção Básica. Brasília: Ministério da Saúde; 2012. [citado 2017 Maio 12]. Disponível em: <http://189.28.128.100/dab/docs/ publicacoes/geral/pnab.pdf>. 
30. Brasil. Secretaria de Educação Fundamental. Parâmetros curriculares nacionais: introdução aos parâmetros curriculares nacionais. Brasília: MEC/SEF; 1997 [citado 2017 Maio 12]. Disponível em: <http://portal.mec.gov.br/seb/arquivos/pdf/ livro01.pdf>.
31. Canguilhem GO. O normal e o patológico. $6^{\mathrm{a}}$ ed. Rio de Janeiro: Forense Universitária; 2009.

Received on: 4/5/2017

Final version resubmitted on: 23/10/2017

Approved on: 14/11/2017 